\title{
Originals
}

\section{In vitro activity of biosynthetic human diarginylinsulin}

\author{
S. Zeuzem ${ }^{1}$, E.Stah $1^{1}$, E. Jungmann ${ }^{1}$, M. Zoltobrocki ${ }^{2}$, K. Schöffling ${ }^{1}$ and W. F. Caspary ${ }^{1}$ \\ 1 Zentrum der Inneren Medizin, Klinikum der Johann Wolfgang Goethe-Universität and \\ ${ }^{2}$ Hoechst AG, Klinische Forschung, Frankfurt am Main, FRG
}

Summary. In diarginylinsulin two arginine residues are located at the C-terminal end of the B-chain ( $\mathrm{Arg}^{\mathrm{B} 11}$ and $\operatorname{Arg}^{\mathrm{B} 22}$. This accounts for a shift of the isoelectric point from $\mathrm{pH} 5.4$ in native insulin to $\mathrm{pH} 7.0$ in diarginylinsulin leading to pharmacodynamic characteristics of an intermediate acting insulin when administered s.c. as $\mathrm{pH} 4.0-5.0$ solution. We have investigated insulin receptor binding and biological activity of biosynthetic human diarginylinsulin in human adipocytes and compared to native insulin and proinsulin. Association- and dissociation studies of insulin receptor binding revealed no differences for diarginylinsulin and native insulin. In competition studies under steady-state binding conditions, half-maximal displacement of tracer occurred at $352 \pm 33 \mathrm{pmol} / 1,337 \pm 32 \mathrm{pmol} / 1$ and $3640 \pm 480 \mathrm{pmol} / 1$ for diarginylinsulin, insulin and proinsulin, respectively. The biologic potency of human diarginylinsulin was evaluated by the ability to stimulate D-glucose transport and by the assessment of the antilipolytic activity. Activation of D-glucose transport was half-maximal at $49.6 \pm 5.4 \mathrm{pmol} / \mathrm{l}$ (diarginylinsulin), $44.8 \pm 5.8 \mathrm{pmol} / 1$ (insulin) and at $476.7 \pm 134.3 \mathrm{pmol} / \mathrm{l}$ (proinsulin). Half-maximal inhibition of lipolysis occurred at $13.9 \pm 3.4 \mathrm{pmol} / \mathrm{l}, 15.4 \pm 2.9 \mathrm{pmol} / \mathrm{l}$ and $138.4 \pm 38.6 \mathrm{pmol} / \mathrm{l}$, respectively. In conclusion, diarginylinsulin has almost identical insulin receptor binding characteristics and full biological activity in vitro compared to native insulin. This pharmacodynamically intermediate acting insulin preparation is therefore of potential therapeutical value.

Key words: Intermediate acting insulin, biosynthetic human diarginylinsulin, insulin receptor binding, glucose transport, anti-lipolysis, protamine allergy, proinsulin.
In the bioconversion process of proinsulin to insulin several intermediate products physiologically occur. Diarginylinsulin is one of these intermediate metabolites and differs from native insulin by two remaining arginine residues at the $\mathrm{C}$-terminal end of the $\mathrm{B}$-chain [1-6] (Fig. 1). The two arginine residues at the $\mathrm{C}$-terminal end of the B-chain in diarginylinsulin account for a shift of the isoelectric point from $\mathrm{pH} 5.4$ in native insulin to $\mathrm{pH} 7.0$ in diarginylinsulin [4].

Diabetic patients receiving daily s.c. injections of insulin containing protamine appear to have a 40 to 50 -fold increase in the risk of life-threatening reactions when given protamine i.v. for reversal of heparin anticoagulation during vascular surgery, cardiac catheterization or dialysis $[8,9]$.

Attempts have been made to find an insulin analogue which retains full biological activity and has an intermediate or long-lasting action without the addition of a retardant. Due to the shift of the isoelectric point to $\mathrm{pH} 7.0$ diarginylinsulin is least soluble at a physiological $\mathrm{pH}$. When this insulin analogue is injected s. c. as pH 4.0-5.0 solution it has the pharmacodynamic characteristics of an intermediate acting NPH-insulin preparation.

However, previous studies revealed a reduced biological activity of porcine diarginylinsulin $[7,10,11]$. By application of recombinant DNA-technology biosynthetic human diarginylinsulin became available. The in vitro bi-

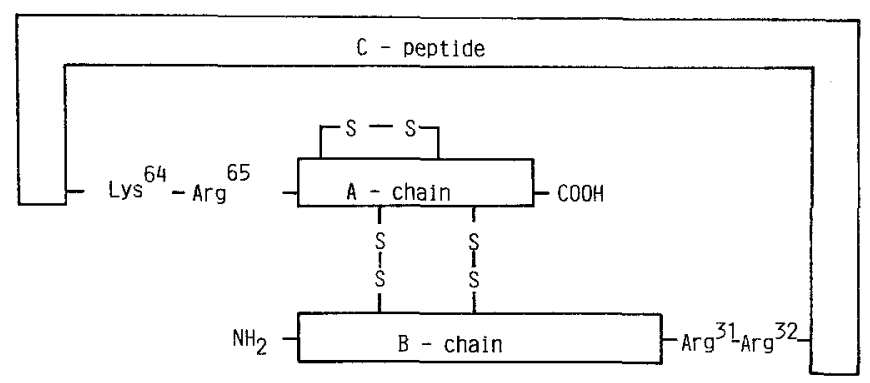

Fig. 1. Scheme of the proinsulin molecule. Diarginylinsulin occurs in the bioconversion process of proinsulin to insulin and differs from native insulin by two remaining arginine residues at the C-terminal end of the B-chain 
ological activity of the human diarginylinsulin has not yet been investigated in isolated human adipocytes. In this study we describe the in vitro characteristics of this insulin analogue with respect to insulin receptor binding, degradation, activation of D-glucose transport and inhibition of catecholamine stimulated lipolysis. Biosynthetic human diarginylinsulin is compared to native human insulin and biosynthetic human proinsulin.

\section{Subjects, materials and methods}

\section{Materials}

Crystalline human diarginylinsulin and native human insulin as well as the respective $\left(\left[{ }^{125} \mathrm{I}\right] \mathrm{Tyr}^{\mathrm{A} 14}\right)$-monoiodinated insulin preparations (specific activity $340 \mathrm{mCi} / \mathrm{mg}$ ) were provided by Hoechst $A G$ (Frankfurt, FRG). Biosynthetic human proinsulin and radiolabelled ([125I]Ty $\mathrm{T}^{79}$ )-proinsulin (specific activity $216 \mathrm{mCi} / \mathrm{mg}$ ) were a gift from the Eli Lilly Laboratories (Indianapolis, Ind., USA). Proinsulin has a different numerical sequence of the carboxyterminal amino acids than insulin because of the connecting peptide (C-peptide). In fact the iodination of the tyrosine residue at position 79 in proinsulin is equivalent to the iodinated tyrosine in position A14 after cleavage of the C-peptide $[12,13]$. Iodination of the tyrosine residue in position A14 (diarginylinsulin, native insulin) or 79 (proinsulin) does not influence receptor binding characteristics or biological activity [14-16].

Potency and purity of all investigated insulins were checked by HPLC according to methods described in the United States pharmacopoea (USP XXI). No cocrystallization was detectable by HPLC.

Crude collagenase was obtained from Sigma (type II, lot $102 \mathrm{~F}$ 6805). Human serum albumin was purchased from Behringwerke (Marburg, FRG). U-14 C-D-glucose (specific activity $270 \mathrm{mCi} / \mathrm{mmol}$ ) was obtained from Amersham (Braunschweig, FRG), phloretin from Sigma (St.Louis, Mo., USA), silicone oil (density $0.97 \mathrm{~g} / \mathrm{ml}$ ) from Serva Feinbiochemica (Heidelberg, FRG). All other chemicals were purchased from Merck (Darmstadt, FRG).

\section{Preparation of isolated adipocytes}

Subcutaneous adipose tissue (about $45 \mathrm{~g}$ ) was obtained from the abdomen of patients undergoing elective gastroenterological surgery. No subject suffered from any endocrine or metabolic disorder or was taking drugs known to affect metabolism. Impaired glucose tolerance was excluded by measuring the fasting blood glucose concentration and the $2 \mathrm{~h}$ value after a $75 \mathrm{~g}$ oral glucose load according to World Health Organisation criteria [17]. The study was approved by the local ethical committee in accordance with the Declaration of Helsinki and informed consent was obtained from the patients.

The adipose tissue was finely chopped and incubated for $90 \mathrm{~min}$ at $37^{\circ} \mathrm{C}$ in a Hepes buffer ( $\left.\mathrm{pH} 7.4\right)$, containing human serum albumin $(25 \mathrm{~g} / \mathrm{l})$ and collagenase $(0.5 \mathrm{~g} / \mathrm{l})$. The isolated adipocytes were subsequently washed five times in a Hepes buffer containing $50 \mathrm{~g} / \mathrm{l}$ human albumin $[18,19]$. The diameters of adipocytes $(n=200)$ were measured at 200 -fold magnification using an eyepiece micrometer. Surface area and volume were calculated for every cell diameter. The cell diameter of the isolated fat cells averaged $102 \pm 7 \mu \mathrm{m}$.

\section{Insulin receptor binding and degradation}

Insulin receptor binding studies to isolated human adipocytes $(300 \mu \mathrm{l}$ cell suspension with an adipocyte volume fraction of 0.05 , i.e. about $1 \times 10^{5}$ cells $/ \mathrm{ml}$ cell suspension) were performed in a
Hepes buffer $(10 \mathrm{mmol} / 1$ Hepes, $50 \mathrm{~g} / \mathrm{l}$ human serum albumin, $\mathrm{pH} 7.4$ ) at $37^{\circ} \mathrm{C}$. Each ${ }^{125}$ I-labelled ligand (final concentration $20 \mathrm{pmol} / 1)$ was incubated with and without increasing amounts of unlabelled diarginylinsulin, native insulin or proinsulin, respectively. The reaction was stopped by adding $10 \mathrm{ml}$ of chilled $0.154 \mathrm{~mol} / \mathrm{l}$ $\mathrm{NaCl}$ and subsequent centrifugation through silicone oil $[18,19]$. Non-specific binding was measured by incubating tracer in the presence of a large excess of unlabelled insulin. Non-specific binding accounted for $9.7 \pm 1.6 \%$ (diarginylinsulin), $9.7 \pm 1.4 \%$ (native insulin) and $24.4 \pm 2.6 \%$ (proinsulin) of the cell-bound fraction at tracer concentration.

For association studies the ${ }^{125}$ I-labelled ligands were incubated for the time indicated ( $1 \mathrm{~min}$ to $240 \mathrm{~min}$ ) and the reaction was terminated as described above. At each time point the non-specific binding was measured and subsequently subtracted from the corresponding data for total binding.

Dissociation rates were determined by first preincubating isolated human adipocytes at $37^{\circ} \mathrm{C}$ with either $\left(\left[{ }^{125} \mathrm{I}\right] \mathrm{Tyr}^{\mathrm{Al} 4}\right)$-diarginylinsulin or $\left(\left[{ }^{125} \mathrm{I}\right] \mathrm{Tyr}^{\mathrm{A} 14}\right)$-insulin for $90 \mathrm{~min}$ to achieve steady-state binding conditions. Each incubation mixture was then centrifuged for $60 \mathrm{~s}$ and the infranatant removed. The adipocytes were rapidly washed twice by diluting to the original volume with buffer at $4^{\circ} \mathrm{C}$ and repeating the centrifugations and aspirations. After the third aspiration, the cells were diluted to the orginal volume either with buffer alone or buffer to which either diarginylinsulin, native insulin or proinsulin at a final concentration of $0.2 \mu \mathrm{mol} / 1$ was added $\left(22^{\circ} \mathrm{C}\right)$. At this hormone concentration a maximal effect of ${ }^{125} \mathrm{I}$-insulin dissociation is reported $[20,21]$. The reaction was stopped at the times indicated (10 min to $180 \mathrm{~min}$ ) and cell-associated radioactivity was determined [21]. Results are expressed as percentage specific binding per $10 \mathrm{~cm}^{2}$ plasma membrane surface area $[22,23]$.

Total degradation (cellular and extracellular) of $\left(\left[{ }^{125} \mathrm{I}\right] \mathrm{Tyr}^{\mathrm{A} 14}\right)$ diarginylinsulin, $\left.\left({ }^{[25} \mathrm{I}\right] \mathrm{Tyr}^{\mathrm{A} 14}\right)$-insulin or $\left.\left({ }^{[25} \mathrm{I}\right] \mathrm{Tyr}^{\mathrm{A} 14}\right)$-proinsulin was assessed by the trichloracetic acid ( $12 \%$ weight/volume) precipitation method [24]. Extracellular degradation (as assessed in the presence of $0.1 \mu \mathrm{mol} / 1$ insulin accounted for less than $15 \%$ of the total degradation for all three investigated insulins.

\section{Measurement of insulin stimulated glucose uptake}

Initial D-glucose uptake was measured using the method described by Pedersen and Gliemann [25] and modified by Zeuzem and Taylor [26]. Human adipocytes $(40 \mu \mathrm{l}$ cell suspension with an adipocyte volume fraction of 0.40 , i. e. about $0.8 \times 10^{6}$ cell.s $/ \mathrm{ml}$ ) were preincubated with and without increasing concentrations of diarginylinsulin, native insulin or proinsulin for $180 \mathrm{~min}$. The incubation was started by a direct injection of $12 \mu \mathrm{U}-{ }^{14} \mathrm{C}$-D-glucose into the cell suspension (final concentration $20 \mu \mathrm{mol} / \mathrm{l}$ ) and then stopped by the addition of $3 \mathrm{ml}$ of $154 \mathrm{mmol} / \mathrm{l} \mathrm{NaCl}$, containing $0.3 \mathrm{mmol} / 1 \mathrm{phloretin,} \mathrm{pH} 7.4$. Silicone oil was layered on the surface and the tubes were centrifuged within $2 \mathrm{~min}$ for $90 \mathrm{~s}$ at $3000 \mathrm{~g}$. The cell pellet was then immediately harvested and added to $5 \mathrm{ml}$ scintillation fluid.

Extracellular trapped radioactivity was measured by adding $3 \mathrm{ml}$ of the phloretin solution to the cell suspension before incubation with $\mathrm{U}-{ }^{14} \mathrm{C}-\mathrm{D}$-glucose and subsequently subtracted from all observed values. Results are expressed as pmol D-glucose taken up per $10 \mathrm{~cm}^{2}$ plasma membrane surface area per $20 \mathrm{~s}$ [23]. The coefficient of variation of the assay was $9.0 \%$ for basal and $11.4 \%$ for maximal uptake.

\section{Measurement of the antilipolytic insulin effect}

Human adipocytes $(500 \mu \mathrm{l}$ cell suspension with an adipocyte volume fraction of 0.15 , i. e. about $0.3 \times 10^{6}$ cells $/ \mathrm{ml}$ ) were preincubated with and without increasing concentrations of diarginylinsulin, native insulin and proinsulin for $180 \mathrm{~min}$ at $37^{\circ} \mathrm{C}$ to achieve steady-state binding conditions. Lipolysis was stimulated by noradrenaline 


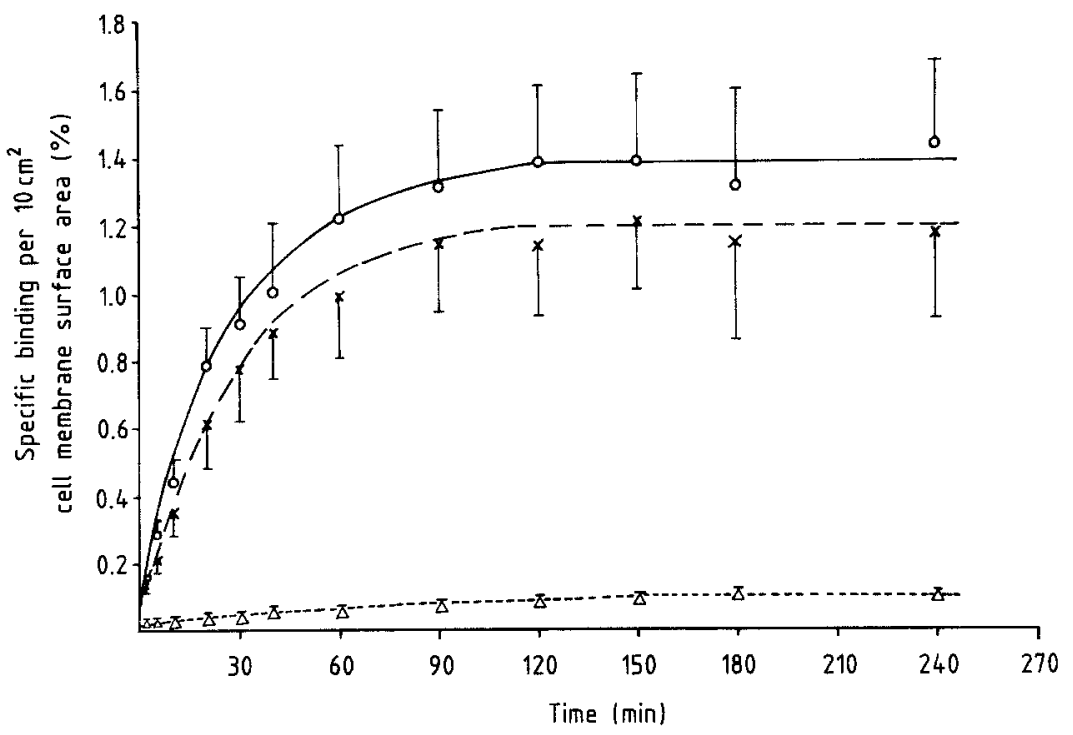

Fig. 2. Association kinetics. Time course of ${ }^{125}$ I-diarginylinsulin $(0-0),{ }^{125} \mathrm{I}$-insulin $(x---x)$ and ${ }^{125} \mathrm{I}$-proinsulin $(\Delta---\Delta)$ binding $(n=4)$. Isolated human adipocytes were incubated at $37^{\circ} \mathrm{C}$ and the reaction was stopped at the indicated time points. All data are corrected for non-specific binding (final concentration $1.7 \mu \mathrm{mol} / \mathrm{l}$ ) and caffeine (final concentration $0.3 \mathrm{mmol} / \mathrm{l}$ ) and the suspension was further incubated for $60 \mathrm{~min}$. Subsequently the cells were centrifuged through silicone oil and the infranatant was sampled. Glycerol release into the medium was measured using an enzymatic method [27]. Results are expressed as nmol glycerol released per 100,000 cells per $60 \mathrm{~min}$ [23].

\section{Statistical analysis}

All results are presented as mean \pm SEM. Statistical analysis was performed using Student's paired $t$-test.

\section{Results}

\section{Steady-state binding}

To determine when steady-state binding conditions were achieved, the time course of binding for ${ }^{125} \mathrm{I}$-diarginylinsulin, ${ }^{125} \mathrm{I}$-insulin and ${ }^{125} \mathrm{I}$-proinsulin (each concentration $20 \mathrm{pmol} / \mathrm{I}$ ) were studied in parallel at $37^{\circ} \mathrm{C}$. In isolated human adipocytes internalization and degradation of the insulin is minimal even at physiological temperatures [18]. These binding studies therefore reflect primarily the association of each insulin to the cell surface receptors.

${ }^{125} \mathrm{I}$-diarginylinsulin reached half-maximal binding at $19.3 \pm 3.1$ min compared to $19.8 \pm 2.1 \mathrm{~min}$ for native insulin and $40.0 \pm 4.1 \mathrm{~min}$ for proinsulin. ${ }^{125} \mathrm{I}$-diarginylinsulin reached $87 \%$ of its maximal binding at $60 \mathrm{~min}$ and maximal binding at $90 \mathrm{~min}$. Maximal binding was maintained at least up to $4 \mathrm{~h}$. Native ${ }^{125} \mathrm{I}$-insulin reacted similarly, reaching maximal binding also at $90 \mathrm{~min}$. However, human proinsulin attained steady-state binding conditions much slower than diarginyl- and native insulin. Under identical conditions, ${ }^{125}$ I-proinsulin reached $47 \%$ of its maximal binding at $60 \mathrm{~min}$ and maximal binding at $180 \mathrm{~min}$ (Fig. 2). For all competition studies of insulin receptor binding we therefore used an incubation period of 180 min to ensure steady-state conditions for all investigated insulins.

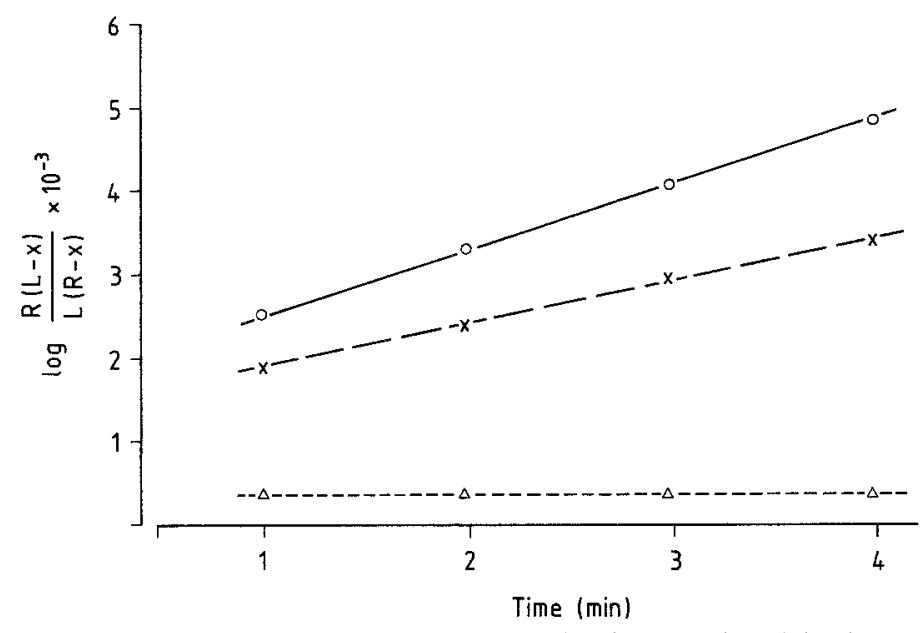

Fig.3. Association rate constants. Second order rate plot of the data shown between 1 and $4 \mathrm{~min}$ in Figure $2(\mathrm{R}=$ receptor number, $\mathrm{L}=\mathrm{li}$ gand concentration, $X=\%$ specific binding at times indicated). The association rate constants $\left(\mathrm{k}_{\mathrm{a}}\right)$ were $1.9 \times 10^{8} \mathrm{~mol} / \mathrm{1}^{-1} \mathrm{~min}^{-1}, 1.3 \times 10^{8}$ $\mathrm{mol} / \mathrm{l}^{-1} \mathrm{~min}^{-1}$ and $0.01 \times 10^{8} \mathrm{~mol} / \mathrm{l}^{-1} \mathrm{~min}^{-1}$ for diarginylinsulin $(0-\infty)$, native insulin $(x-\cdots)$ and proinsulin $(\Delta---\Delta)$, respectively

\section{Kinetic analysis}

The calculated association rate constant [28] $\mathrm{k}_{\mathrm{a}}$ was $1.9 \times 10^{8} \mathrm{~mol} / \mathrm{l}^{-1} \mathrm{~min}^{-1}$ for diarginylinsulin compared to $\mathrm{k}_{\mathrm{a}}=1.3 \times 10^{8} \mathrm{~mol} / \mathrm{1}^{-1} \mathrm{~min}^{-1}$ (insulin) and $\mathrm{k}_{\mathrm{a}}=0.01 \times 10^{8}$ $\mathrm{M}^{-1} \min ^{-1}$ (proinsulin) (Fig. 3 ). The difference between diarginylinsulin and insulin was not significant $(p>0.1)$.

The effect of unlabelled diarginylinsulin, insulin and proinsulin on the dissociation of $\left(\left[^{125} \mathrm{I}\right] \mathrm{Tyr}^{\mathrm{A} 14}\right)$-diarginylinsulin (Fig.4) and ([$\left.{ }^{125} \mathrm{I}\right] \mathrm{Tyr}^{\mathrm{A} 14}$ )-insulin (data not shown) were investigated. The dissociation curves of diarginylinsulin and native insulin were almost identical with a halftime of dissociation of $29.8 \pm 4.2 \mathrm{~min}$ and $28.6 \pm 5.6 \mathrm{~min}$, respectively. The $\mathrm{k}_{\mathrm{d}}$ for dissociation were $2.5 \times 10^{-2} \mathrm{~min}^{-1}$ and $2.7 \times 10^{-2} \mathrm{~min}^{-1}$, respectively. Unlabelled diarginylinsulin and native insulin accelerated the dissociation of the corresponding ${ }^{125}$ I-labelled ligand when compared to the dissociation due to dilution only. Half-maximal disso- 


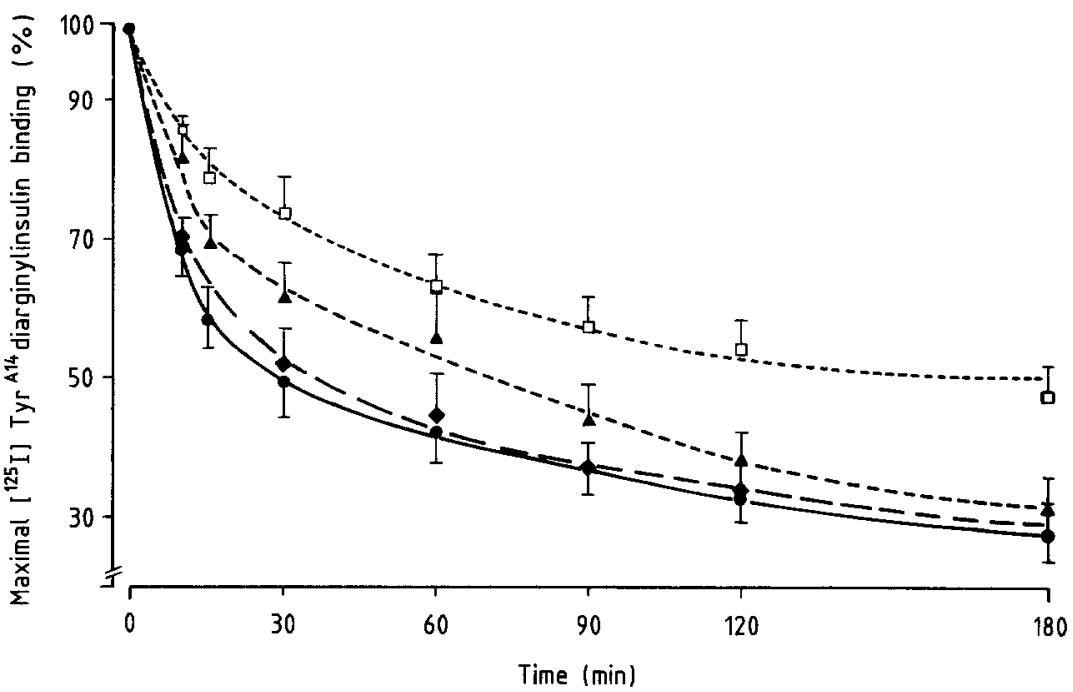

Fig.4. Dissociation kinetics. Time course of ${ }^{125}$ I-diarginylinsulin dissociation. Human adipocytes were preincubated at $37^{\circ} \mathrm{C}$ with ${ }^{125}$ I-diarginylinsulin for $90 \mathrm{~min}$ to achieve steady-state binding conditions $(n=5)$. Subsequently the cells were rapidly washed at $4^{\circ} \mathrm{C}$ and resuspended to the original volume with either buffer alone ( $\square-\cdots-\square$ ) or buffer to which either diarginylinsulin $(\bullet)$, insulin $(\bullet-\bullet)$ or proinsulin ( $0.2 \mu \mathrm{mol} / \mathrm{l}$ was added $\left(22^{\circ} \mathrm{C}\right)$. The reaction was stopped at the times indicated, the data corrected for non-specific binding and expressed as percentage of maximal binding

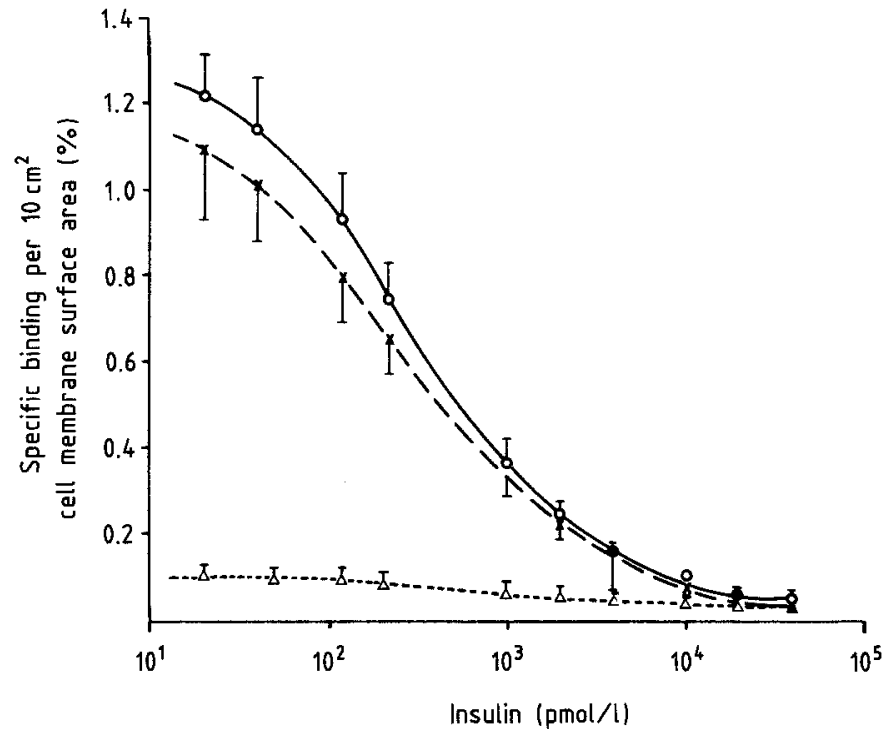

Fig.5. Insulin receptor binding. Specific insulin binding to isolated human adipocytes incubated with $20 \mathrm{pmol} / \mathrm{l}$ monoiodinated tracer at $37^{\circ} \mathrm{C}$ in absence or presence of diarginylinsulin $(\mathrm{O}-\mathrm{O})$, native insulin $(x---x)$ and proinsulin $(\Delta--\Delta)$ in increasing concentrations $(n=7)$

ciation occurred at $178.0 \pm 17.1 \mathrm{~min}$ (dilution only) and at $29.8 \pm 4.2 \mathrm{~min}$ (diarginylinsulin). Proinsulin dissociated ${ }^{125} \mathrm{I}$-diarginylinsulin and ${ }^{125} \mathrm{I}$-insulin much slower with a half-time of $69.0 \pm 14.5 \mathrm{~min}$ and $78.1 \pm 5.4 \mathrm{~min}$, respectively.

\section{Insulin receptor binding}

Competition studies were performed by incubating isolated human adipocytes with human $\left(\left[{ }^{125} \mathrm{I}\right] \mathrm{Tyr}^{\mathrm{A14}}\right)$-diarginylinsulin, $\left.\left({ }^{125} \mathrm{I}\right] \mathrm{Tyr}^{\mathrm{A} 14}\right)$-insulin and $\left(\left[{ }^{125} \mathrm{I}\right]-\mathrm{Tyr}^{79}\right)$-proinsulin and increasing concentrations of unlabelled diarginylinsulin, native insulin and proinsulin, respectively for $180 \mathrm{~min}$ at $37^{\circ} \mathrm{C}$. At equilibrium $1.21 \pm 0.10 \%$ of ${ }^{125} \mathrm{I}-$ diarginylinsulin was bound per $10 \mathrm{~cm}^{2}$ plasma membrane surface area compared to $1.09 \pm 0.13 \%\left({ }^{125} \mathrm{I}\right.$-insulin) and $0.10 \pm 0.03 \%$ ( ${ }^{125} \mathrm{I}$-proinsulin). The difference in maximal binding between diarginyl- and native insulin was not significant $(p>0.1)$.

The displacement curves for diarginyl- and native insulin were similar. Half-maximal displacement of tracer occurred at $352 \pm 33 \mathrm{pmol} / \mathrm{l}, \quad 337 \pm 32 \mathrm{pmol} / \mathrm{l}$ and $3640 \pm 480 \mathrm{pmol} / \mathrm{l}$ for diarginylinsulin, insulin and proinsulin, respectively (Fig. 5). Scatchard analysis [29] of the binding data revealed curvilinear plots for all three investigated insulins. There were no differences between diarginylinsulin and insulin concerning the slopes of the high affinity portions of the plots. As anticipated, the abscissal intercepts (computer modelled, Dr. Schloos, Department of Pharmacokinetics, University of Frankfurt, FRG) yielded similar numbers of receptor sites per cell membrane surface area $\left(7.2,7.7\right.$ and $8.2 \mathrm{fmol}$ per $10 \mathrm{~cm}^{2}$ cell membrane surface area, respectively), indicating that the investigated three ligands bind to a similar number of receptors. The differences between diarginylinsulin and proinsulin were most marked for the high affinity portions of the plots, expressing the marked decrease of the receptor binding affinity of proinsulin.

\section{Degradation}

As measured by solubility in trichloracetic acid $1.5 \%$ of $\left.\left({ }^{125} \mathrm{I}\right] \mathrm{Tyr}^{\mathrm{A} 14}\right)$-diarginylinsulin, $1.3 \%$ of $\left(\left[{ }^{125} \mathrm{I}\right] \mathrm{Tyr}^{\mathrm{A} 14}\right)$-insulin and $0.8 \%$ of $\left.\left({ }^{125} \mathrm{I}\right] \mathrm{Tyr}^{79}\right)$-proinsulin was degraded per $1 \times 10^{5}$ cells $/ \mathrm{ml}$ per $60 \mathrm{~min}$.

\section{Glucose transport}

In isolated human adipocytes basal glucose uptake was $0.80 \pm 0.09 \mathrm{pmol} \cdot 10 \mathrm{~cm}^{2-1} \cdot 20 \mathrm{~s}^{-1}$. Initial D-glucose uptake was half-maximally stimulated at $49.6 \pm 5.4 \mathrm{pmol} / \mathrm{l}$ (diarginylinsulin), at $44.8 \pm 5.8 \mathrm{pmol} / 1$ (native insulin) and at $476.7 \pm 134.3 \mathrm{pmol} / \mathrm{l}$ (proinsulin). Rates of D-glucose uptake achieved by maximal stimulation with diarginylinsulin, insulin and proinsulin were similar $(1.46 \pm 0.17$, $1.45 \pm 0.19$ and $1.41 \pm 0.17 \mathrm{pmol} \cdot 10 \mathrm{~cm}^{2-1} \cdot 20 \mathrm{~s}^{-1}$, respectively). This results in an almost identical dose-response 


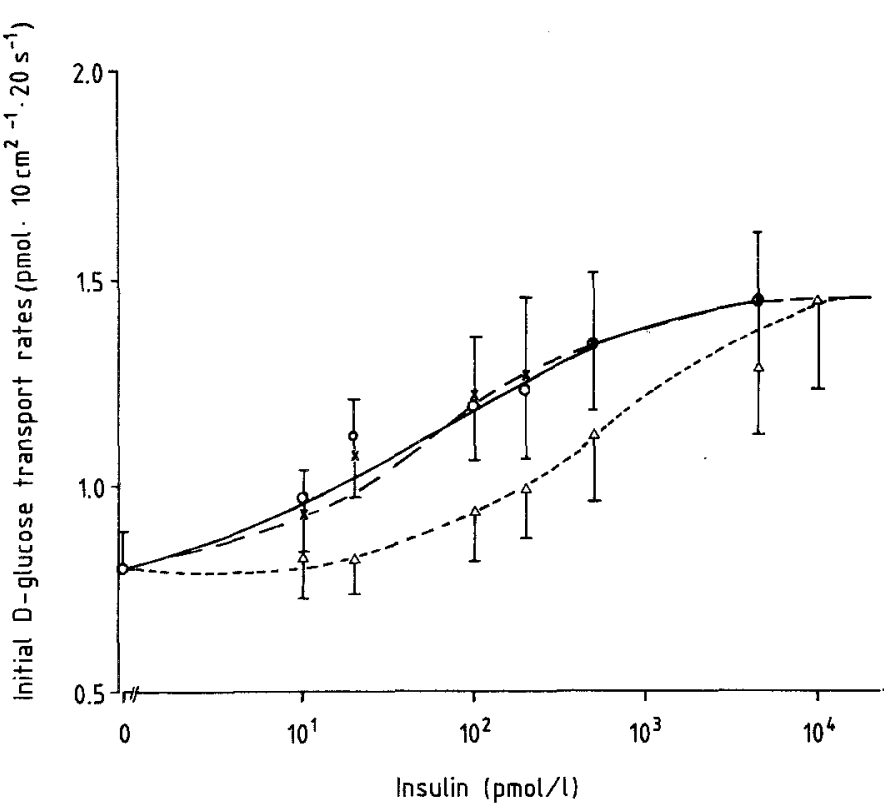

Fig.6. D-glucose transport. Initial rates of D-glucose uptake by human adipocytes incubated at $37^{\circ} \mathrm{C}$ in absence or presence of diarginylinsulin $(0-0)$, insulin $(\times-\cdots \times)$ and proinsulin $(\Delta--\Delta)$ in increasing concentrations $(n=6)$

curve for diarginylinsulin and native insulin. The dose-response curve of proinsulin is shifted to the right, indicating a reduced sensitivity but no decrease in responsiveness (Fig. 6).

\section{Anti-lipolysis}

The glycerol release for noradrenaline and caffeine stimulated lipolysis was $1086 \pm 122 \mathrm{nmol}$ per 100,000 cells per $60 \mathrm{~min}$. Half-maximal inhibition of lipolysis occurred at $13.9 \pm 3.4 \mathrm{pmol} / \mathrm{l}$ (diarginylinsulin), $15.4 \pm 2.9 \mathrm{pmol} / \mathrm{l}$ (insulin) and $138.4 \pm 38.6 \mathrm{pmol} / \mathrm{l}$ (proinsulin). Maximal inhibition of lipolysis was observed at $814 \pm 229 \mathrm{pmol} / \mathrm{l}$, $943 \pm 307 \mathrm{pmol} / \mathrm{l}$ and $75,714 \pm 19,615 \mathrm{pmol} / \mathrm{l}$, respectively. No significant differences were found for the maximal inhibition of lipolysis $(59.4 \pm 6.9 \%, 61.3 \pm 8.8 \%$ and $54.5 \pm 8.3 \%$ ) nor the paradoxical effect of the insulins at high concentrations in stimulating lipolysis (Fig. 7).

\section{Discussion}

The polypeptide chain of proinsulin is ordered as follows: $\mathrm{NH}_{2}$ - B-chain - Arg - Arg - C-peptide - Lys - Arg A-chain- $\mathrm{COOH}$ (Fig. 1). The conversion of proinsulin to insulin in the B-cells of the pancreas occurs by a branched pathway involving the formation of $\mathrm{Arg}^{65} / \mathrm{Gly}^{66}$-split proinsulin and $\mathrm{Arg}^{32} / \mathrm{Glu}^{33}$-split proinsulin, the latter being the preferential cleavage pathway (about 3 to 1 ) $[5,30]$. The next step in the bioconversion process is the formation of des- $\mathrm{Lys}^{64}, \mathrm{Arg}^{65}$-proinsulin and des-Arg ${ }^{31}$,$\mathrm{Arg}^{32}$-proinsulin (des-dipeptide proinsulin intermediates). Cleavage of either intermediate by a trypsin-like endoprotease at the remaining paired dibasic amino acid conversion site, followed by the action of a carboxypeptidase B-like exoprotease to remove $\mathrm{COOH}$-terminal basic residues, yields insulin, C-peptide and stoichiometric quantities of free lysine and arginine. During the last conversion steps of the des-Lys ${ }^{64}, \mathrm{Arg}^{65}$-proinsulin diarginyland monoarginylinsulin occur as intermediates $[3,12]$.

The biological activities of several derivatives (conversion intermediates) of human proinsulin containing peptide bond cleavages or peptide deletions in the connecting peptide region have been investigated by Peavy et al. [31]. At high concentrations each derivative produced the same maximal response. Differences in the relative potency of these analogues, as indicated by the concentration required to produce a half-maximal response, generally agreed with the differences in receptor binding affinity. Interestingly, an apparent discrepancy was described for the des-[Glu $\left.{ }^{33}-\mathrm{Leu}^{56}\right]$-proinsulin. This analogue demonstrated a receptor binding affinity 27 times that of human proinsulin, but a biological activity only nine times that of proinsulin [31]. Des-[ $\left.\mathrm{Glu}^{33}-\mathrm{Leu}^{56}\right]$ proinsulin differs from diarginylinsulin only by nine amino-acids, which remain at the $\mathrm{NH}_{2}$-terminal end of the A-chain $\left(\mathrm{Ala}^{57}\right.$ to $\mathrm{Arg}^{65}$ ). In the present study, however, no differences were observed between receptor binding affinity and biological potency for the diarginylinsulin. The relative binding affinity of human proinsulin was $9.7 \%$ compared to diarginylinsulin, while the relative biological potencies for stimulating glucose-transport and inhibiting lipolysis were $10.4 \%$ and $10.0 \%$, respectively.

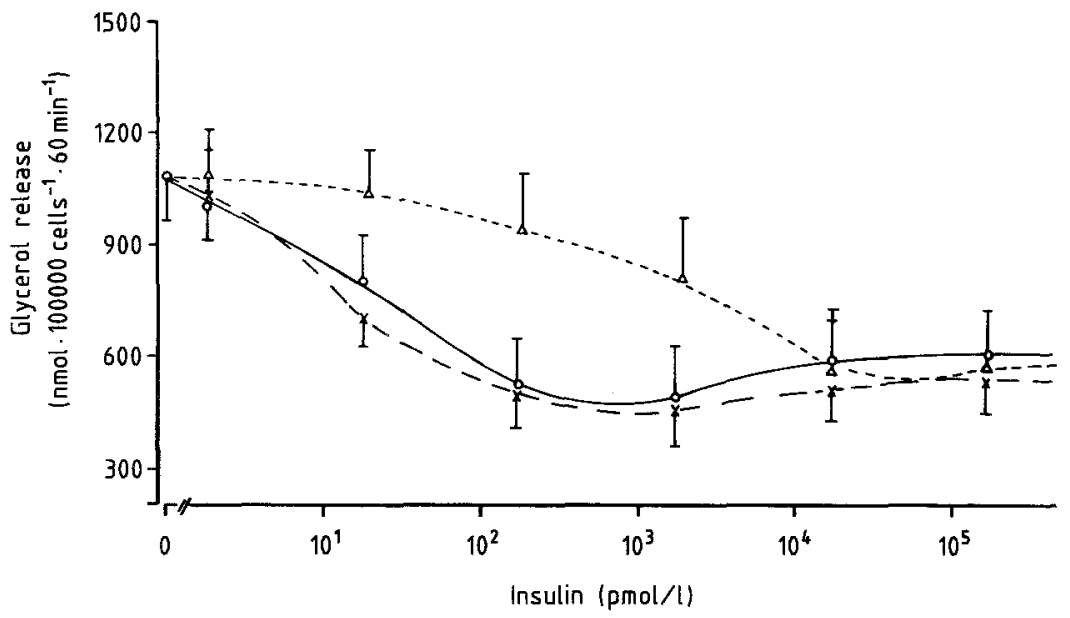

Fig. 7. Anti-lipolysis. Anti-lipolysis by human adipocytes incubated at $37^{\circ} \mathrm{C}$ in absence or presence of diarginylinsulin $(0-0)$, insulin $(x---x)$ and proinsulin $(\Delta-\cdots)$ in increasing concentrations $(n=7)$ 
The proposed insulin receptor binding region of the insulin molecule comprises the amino acids at position $\mathrm{Gly}^{1}$, $\mathrm{Gln}^{5}, \mathrm{Tyr}^{19}$ and $\mathrm{Asn}^{21}$ of the A-chain and the position $\mathrm{Val}^{12}$, $\mathrm{Tyr}^{16}, \mathrm{Arg}^{22}, \mathrm{Gly}^{23}, \mathrm{Ph}^{25}$ and Tyr ${ }^{26}$ of the B-chain $[34,35]$. The almost identical receptor binding affinity of biosynthetic human diarginylinsulin and native insulin implies that the substitution of $\mathrm{Arg}^{\mathrm{B} 31}$ and $\mathrm{Arg}^{\mathrm{B} 32}$ does not affect the binding region and makes conformational changes of this region unlikely.

Kinetic studies showed no differences in the association rate between diarginylinsulin and native insulin. Both ligands were capable of accelerating the dissociation of either ${ }^{125} \mathrm{I}$-diarginylinsulin or ${ }^{125} \mathrm{I}$-insulin. These data suggest that diarginylinsulin is able to exhibit negative cooperative effects to a similar extent as native insulin. Studies with modified insulin analogues have defined the $\mathrm{C}$-terminal end of the B-chain and the position $\mathrm{Asn}^{\mathrm{A} 21}$ as most important for the potency of an insulin analogue to induce negative cooperative effects [36]. The substitution of two further amino-acids at the C-terminal B-chain as in the diarginylinsulin did not influence the negative cooperative properties.

Various chemical substitutions at the $\mathrm{COOH}$-terminal end of the B-chain, e.g. with acetyl residues or butyloxycarbonyl (BOC) derivatives, were reported to cause a $25-$ $56 \%$ decrease in potency [33]. In previous studies the biological activity of porcine diarginylinsulin was found to be reduced by 11 to $60 \%$ compared to native insulin $[7,10,11$, 32].

The results of biosynthetic human diarginylinsulin in this study are in contrast to these previously reported data of porcine diarginylinsulin. However, most of the studies on the biological activity of porcine diarginylinsulin were performed ten or more years ago. The possibility exists that a small amount of contamination with proinsulin or partially cleaved proinsulin had been present, therefore explaining the reduced activity of porcine diarginylinsulin found in these studies. Native porcine and human insulin differ only by one amino acid (alanine and threonine in position B30). The biological activity of both insulins is equivalent. Therefore species differences as an explanation of the described differences appear to be unlikely. However, the two arginine residues are substituted at the position B30. It remains questionable whether the addition of two arginine residues at $\mathrm{Ala}^{\mathrm{B} 30}$ instead of $\mathrm{Thr}^{\mathrm{B} 30} \mathrm{can}$ lead to a reduced biological activity.

The reported relative potencies of human proinsulin in vitro range between 1 and $16 \%$ that of native insulin [10, $12,20,37,38]$. In this study, using isolated human adipocytes, we observed a relative potency of $9.3 \%$ for receptor binding, $9.4 \%$ and $11.1 \%$ for activation of $\mathrm{D}$-glucose transport and inhibition of lipolysis, respectively.

Measurement of total degradation showed no difference between ${ }^{125} \mathrm{I}$-diarginylinsulin and ${ }^{125} \mathrm{I}$-insulin. The first step of insulin degradation may be mediated by a "insulin-specific protease" [12]. No difference in substrate activity of an insulin-specific protease was reported for porcine diarginylinsulin and insulin, the ability of the enzyme to degrade proinsulin, however, was negligible [39]. In our study the degradation of ${ }^{125}$ I-proinsulin was reduced in comparison to diarginylinsulin and native in- sulin. Studies of ${ }^{125}$ I-proinsulin internalization and degradation in rat fat cells by Podlecki et al. have suggested that internalization of receptor bound proinsulin proceeds to a greater degree than does insulin, but once proinsulin is internalized the rate of degradation was also found markedly reduced compared to insulin [20].

In comparison to insulin, little attention has been paid to the immunogenicity of retardants. Protamine, a commonly used retardant of insulin absorption, is a basic polypeptide. Sera from patients treated with different types of protamine-insulin showed a high prevalence of circulating IgG-antibody to protamine. Rosenthal found that some protamine-insulin treated patients had responded immunologically to protamine as judged by the lymphocyte proliferation test [41]. In diabetic patients treated with protamine-insulins, the increased risk of serious reactions when i.v. protamine was given appeared to be caused largely by antibody-mediated mechanisms [8]. In a study by Kurtz et al. a relationship between insulin and protamine antigenicity was shown, suggesting that the protamine-insulin complex is itself immunogenic [40]. In several reports local and systemic reactions specifically to protamine and zinc have been described [42-46]. However, the actual percentage of diabetic patients in whom additives, such as protamine or zinc, are a cause of "insulin" allergy is unknown.

In conclusion, biosynthetic human diarginylinsulin and native insulin have almost identical in vitro bioactivities in isolated human adipocytes. Further investigations concerning the metabolic activity and the immunogenicity of diarginylinsulin in vivo as well as detailed absorption kinetic studies are required. By application of recombinant DNA technologies, it is possible to prepare large quantities of human diarginylinsulin. Thus, biosynthetic diarginylinsulin is a potential candidate for an intermediate acting insulin preparation containing no retarding substances.

Acknowledgements. We thank Mrs. H. Höltzen and Mrs. I. Kirschenbauer for their excellent technical assistance.

\section{References}

1. Steiner DF, Oyer PE (1967) The biosynthesis of insulin and a probable precursor of insulin by a human islet cell insulinoma. Proc Natl Acad Sci USA 57: 473-480

2. Steiner DF, Cunningham D, Spigelman L, Alten B (1967) Insulin biosynthesis: evidence for a precursor. Science 157:697-700

3. Kemmler W, Peterson JD, Steiner DF (1971) Studies on the conversion of proinsulin to insulin. I. Conversion in vitro with trypsin and carboxypeptidase B. J Biol Chem 246: 6786-6791

4. DeHaen C, Little SA, May JM, Williams RH (1978) Characterization of proinsulin-insulin intermediates in human plasma. J Clin Invest 62: 727-737

5. Given BD, Cohen RM, Shoelson SE, Frank BH, Rubenstein AH, Tager HS (1985) Biochemical and clinical implications of proinsulin conversion intermediates. J Clin Invest 76: 1398-1405

6. Gutman RA, Lazarus NR, Recant L (1972) Electrophoretic characterization of circulating human proinsulin and insulin. Diabetologia 8: 136-140

7. Chance RE (1972) Amino acid sequences of proinsulin and intermediates. Diabetes 21: 461-467 
8. Weiss ME, Nyhan D, Peng Z, Horrow JC, Lowenstein E, Hirshman C, Adkinson NF Jr (1989) Association of protamine IgE and $\mathrm{IgG}$ antibodies with life-threatening reactions to intravenous protamine. N Engl J Med 320: 886-892

9. Stewart WJ, McSweeney SM, Kellett MA, Faxon DP, Ryan TJ (1984) Increased risk of severe protamine reactions in NPH in sulin-dependent diabetics undergoing cardiac catheterization. Circulation 70: 788-792

10. Yu SS, Kitabchi AE (1973) Biological activity of proinsulin and related polypeptides in the fat tissue. J Biol Chem 248: 3753-3761

11. Freychet $P(1974)$ The interactions of proinsulin with insulin receptors on the plasma membrane of the liver. J Clin Invest 54: 1020-1031

12. Kitabchi AE (1977) Proinsulin and C-peptide: a review. Metabolism 26: 547-587

13. Chan SJ, Weiss J, Konrad M, White T, Bahl C, Tu SD, Marks D, Steiner DF (1981) Biosynthesis and periplasmic segregation of human proinsulin in Escherichia coli. Proc Natl Acad Sci USA 78: 5401-5405

14. Gliemann J, Sonne O, Linde S, Hansen B (1979) Biological potency and binding affinity of monoiodoinsulin with iodine in tyrosine $\mathrm{A}^{14}$ or tyrosine $\mathrm{A}^{19}$. Biochem Biophys Res Commun 87: $1183-1190$

15. Linde S, Hansen B, Sonne O, Holst JJ, Gliemann J (1981) Tyrosine $A_{14}\left({ }^{125} \mathrm{I}\right)$-monoiodoinsulin. Preparation, biologic properties and long-term stability. Diabetes $30: 1-8$

16. Frank BH, Beckage MJ, Willey KA (1983) High performance liquid chromatographic preparation of single site carrier-free pancreatic polypeptide hormone radiotracers. J Chromatogr 266: $239-248$

17. WHO study group (1985) Diabetes mellitus. Technical Report series 727, Geneva, p 11

18. Pederson O, Hjollund E, Beck-Nielsen H, Lindskov HO, Sonne O, Gliemann J (1981) Insulin receptor binding and receptormediated insulin degradation in human adipocytes. Diabetologia 20: 636-641

19. Zeuzem S, Taylor R, Agius L, Albisser AM, Alberti KGMM (1984) Differential binding of sulphated insulin to adipocytes and hepatocytes. Diabetologia 27: 184-188

20. Podlecki DA, Frank BH, Olefsky JM (1984) In vitro characterization of biosynthetic human proinsulin. Diabetes 33: 111118

21. DeMeyts P, Bianco AR, Roth J (1976) Site-site interactions among insulin receptors. Characterization of the negative cooperativity. J Biol Chem 241: 1877-1888

22. Olefsky JM (1976) Decreased insulin binding to adipocytes and circulating monocytes from obese subjects. J Clin Invest 57 : $1165-1172$

23. Pedersen O, Hjollund E, Linkskov HO (1982) Insulin binding and action on fat cells from young healthy females and males. Am J Physiol 243: E158-E167

24. Freychet P, Kahn R, Roth J, Neville DM (1972) Insulin interactions with liver plasma membranes: independence of binding of the hormone and its degradation. J Biol Chem 247:3953-3961

25. Pedersen O, Gliemann J (1981) Hexose transport in human adipocytes: factors influencing the response to insulin and kinetics of methylglucose and glucose transport. Diabetologia 20:630635

26. Zeuzem S, Taylor R (1985) Assessment of initial hexose uptake into adipocytes using the physiological substrate $\mathrm{D}$-glucose. Particular relevance to human adipocytes. Scand J Clin Lab Invest 45: $545-551$

27. Eggstein M (1966) Eine neue Bestimmung der Neutralfette im Blutserum und Gewebe. II. Zuverlässigkeit der Methode, andere Neutralfettbestimmungen, Normalwerte für Triglyceride und Glycerin im menschlichen Blut. Klin Wochenschr 44: 267-273
28. Yamamura HI, Enna J, Kuhar M (1978) Neurotransmitter receptor binding. Raven Press, New York, $\mathrm{p} 78$

29. Scatchard G (1949) The attractions of proteins for small molecules and ions. Ann NY Acad Sci 51: 660-672

30. Tager HS, Patzelt C, Assoian RK, Chan SJ, Duguid JR, Steiner DF (1980) Biosynthesis of islet cell hormones. Ann NY Acad Sci 343: 133-147

31. Peavy DE, Brunner MR, Duckworth WC, Hooker CS, Frank $\mathrm{BH}$ (1985) Receptor binding and biological potency of several split forms (conversion intermediates) of human proinsulin. J Biol Chem 260: 13989-13994

32. Frank BH, Pekar AH, Veros AJ (1972) Insulin and proinsulin conformation in solution. Diabetes 21: 486-491

33. Gliemann J, Gammeltoft S (1974) The biological activity and the binding affinity of modified insulins determined on isolated rat fat cells. Diabetologia 10: 105-113

34. Blundell TL, Dodson GG, Hodgkin DC, Mercola DA (1972) Insulin: the structure in the crystal and its reflection in chemistry and biology. Adv Protein Chem 26: 279-402

35. Pullen RA, Lindsay DG, Wood SP, Tickle IJ, Blundell TL, Wollmer A, Krail G, Brandenburg D, Zahn H, Gliemann J, Gammeltoft S (1976) Receptor-binding region of insulin. Nature 259 : 369-373

36. DeMeyts P, Van Obberghen E, Roth J, Wollmer A, Brandenburg D (1978) Mapping of the residues responsible for the negative cooperativity of the receptor-binding region of insulin. Nature 273: 504-509

37. Peavy DE, Abram JD, Frank BH, Duckworth WC (1984) In vitro activity of biosynthetic human proinsulin. Receptor binding and biologic potency of proinsulin and insulin in isolated rat adipocytes. Diabetes 33: 1062-1067

38. Ciaraldi TP, Brady D, Olefsky JM (1986) Kinetics of biosynthetic human proinsulin action in isolated rat adipocytes. Diabetes 35 : 318-323

39. Baskin FK, Kitabchi AE (1973) Substrate studies for insulin-specific protease. Eur J Biochem 37: 489-496

40. Kurtz AB, Gray ŔS, Markanday S, Nabarro JDN (1983) Circulating IgG antibody to protamine in patients treated with protamine-insulins. Diabetologia 25:322-324

41. Rosenthal AS (1980) Regulation of the immune response - role of the macrophage. N Engl J Med 20: 1153-1156

42. Shore PN, Shelley WB, Kyle GC (1975) Chronic urticaria from isophane insulin therapy. Arch Dermatol 111: 9497

43. Sánchez MB, Paolillo M, Chacón RS, Camejo M (1982) Protamine as a cause of generalised allergic reactions to NPH insulin. Lancet I: 1243

44. Feinglos MN, Jegasothy BV (1979) "Insulin" allergy due to zinc. Lancet I: $122-124$

45. Bruni B, Campana M, Gamba S, Grassi G, Blatto A (1985) A generalized allergic reaction due to zinc in insulin preparation. Diabetes Care 8:201

46. Bruni B, Barolo P, Gamba S, Grassi G, Blatto A (1986) Case of generalized allergy due to zinc and protamine in insulin preparation. Diabetes Care 9: 552

Received: 11 July 1989

and in revised form: 25 September 1989

Dr. S.Zeuzem

Zentrum der Inneren Medizin

Klinikum der Johann Wolfgang Goethe-Universität

Theodor-Stern-Kai 7

D-6000 Frankfurt a. $M$.

FRG 